\title{
PENDAMPINGAN PEMBENTUKAN BADAN USAHA MILIK DESA DI DESA NAPAN, BIKOMI UTARA, TIMOR TENGAH UTARA
}

\author{
Yakobus Kolne ${ }^{1)}$ dan Dian Festianto ${ }^{2)}$ \\ Program Studi IImu Pemerintahan, Fakultas Ilmu Sosial dan Politik, \\ Universitas Timor, Indonesia ${ }^{1,2)}$ \\ Pos-el: graciakolne@gmail.com ${ }^{1)}$
}

Dikirim: 2 Juli 2018

Direvisi: 30 Juli 2018
Diterbitkan: 29 Agustus 2018

\begin{abstract}
Abstrak
Pengabdian kepada masyarakat yang dilakukan di Desa Napan Kecamatan Bikomi Utara ini dilaksanakan selama 2 (dua) hari yakni tanggal 26-27 Juli 2017. Kegiatan ini bertujuan untuk memberikan sumbangan pemikiran dan penyuluhan tentang pembentukan Badan Usaha Milik Desa BUMDes. Pembentukan BUMDes merupakan perwujudan amanat UU NO. 6 tahun 2014 tentang Desa, dimana pemerintah desa dituntut untuk melaksanakan pengelolaan keuangan desa dan pengelolaan kekayaan desa. Desa sebagai kesatuan masyarakat yang otonom, memiliki sumber-sumber kekayaan dan pendapatan yang harus dikelola secara baik dan profesional demi peningkatan kesejahteraan masyarakat desa. BUM Desa merupakan suatu badan usaha alternatif yang perlu dikembangkan untuk mendorong perekonomian desa, dengan harapan dapat menciptakan sumber daya ekonomi baru untuk memanfaatkan keterbatasan-keterbatasan sumber daya yang dimiliki desa. Oleh karena itu kegiatan pengabdian ini mendapat sambutan yang sangat baik dan antusiasme dalam merespons materi yang disampaikan sangat baik yakni: Meningkatnya pengetahuan dan pemahaman tentang isi, maksud dan tujuan dari pada pentingnya pembentukan BUMDes, meningkatnya pengetahuan dan pemahaman tentang kerja pengurus dalam mencegah terjadinya penyimpangan dalam pengelolaan BUMDes dan selanjutnya bersama Pemerintah Desa dan Badan Permusyawaratan Desa (BPD) serta badan pengurusnya dapat merumuskan Peraturan Desa/Keputusan Kepala Desa tentang Penetapan Badan Pengurus BUMDes Napan Kecamatan Bikomi Utara, Kabupaten TTU. Kata Kunci: pendampingan, pembentukan, Pengelolaan, dan BUMDes
\end{abstract}

\section{PENDAHULUAN}

Dalam UU Nomor 6 Tahun 2014 adalah meningkatnya peran serta masyarakat dalam penyelenggaraan pemerintahan desa secara akuntabel dan transparan. Pemerintah Desa dituntut untuk melaksanakan pengelolaan keuangan desa dan pengelolaan kekayaan desa dengan lebih baik sesuai dengan PP Nomor 43/2014. Desa 
sebagai kesatuan masyarakat yang otonom, memiliki sumber-sumber kekayaan dan pendapatan sendiri yang harus dikelola secara baik. Sumber potensi desa tersebut harus dimanfaatkan secara optimal dan profesional demi peningkatan kesejahteraan masyarakat desa.

Didin 2010 (dalam Solekhan, 2014:43) mengemukakan, "Menempatkan kedudukan desa otonom akan membawa perubahan pelaksanaan pemerintahan desa lebih baik, antara lain: (1) satuan-satuan desentralisasi (otonom) lebih fleksibel dalam memenuhi berbagai perubahan yang terjadi dengan cepat, (2) satuan-satuan desentralisasi (otonom) dapat melaksanakan tugas lebih efektif dan lebih efisien, (3) satuan-satuan desentralisasi (otonom) lebih inovatif, (4) satuan-satuan desentralisasi (otonom) mendorong tumbuhnya sikap moral yang lebih tinggi, komitmen yang lebih tinggi dan lebih produktif."

Pada kenyataan yang ada, memperlihatkan bahwa saat ini rata-rata tingkat pendidikan struktur pemerintahan desa dan masyarakat relatif rendah, ditambah lagi tidak efektifnya pendampingan yang dilakukan oleh pihak kecamatan menyebabkan tingkat kemampuan struktur pemerintahan desa dan masyarakat terbatas. Konsekuensinya, upaya untuk meningkatkan kompetensi penyelenggaraan pemerintahan desa termasuk pengelolaan potensi-potensi desa yang kemudian dikelola dalam struktur organisasi desa yaitu Badan Usaha Milik Desa memerlukan upaya pendampingan teknis oleh akademisi. Hal ini karena dengan adanya pembentukan BUMDes dapat menjalankan usaha di bidang ekonomi dan/atau pelayanan umum sesuai dengan ketentuan peraturan perundang-undangan. BUM Desa merupakan suatu badan usaha alternatif yang perlu dikembangkan untuk mendorong perekonomian desa, dengan harapan dapat menciptakan sumber daya ekonomi baru untuk memanfaatkan keterbatasan-keterbatasan sumber daya yang dimiliki desa.

Hasil pendapatan BUM Desa dapat dimanfaatkan untuk: 1) pengembangan usaha dan 2) pembangunan desa, pemberdayaan masyarakat desa dan pemberian bantuan untuk masyarakat miskin melalui hibah, bantuan sosial dan kegiatan dana bergulir yang ditetapkan dalam Anggaran Pendapatan dan Belanja Desa (Pasal 89, UU No.6 Tahun 2014 tentang Desa). Dengan demikian BUM Desa diharapkan menjadi alternatif untuk melindungi dan memberdayakan masyarakat desa, dan menjadi area bagi warga desa untuk bekerjasama membangun serta mengembangkan ekonomi wilayahnya. Pada dasarnya pembentukan dan pengelolaan sumber daya melalui pengembangan usaha 
dan pemberdayaan masyarakat desa belum dikelola secara baik sesuai dengan amanat UU No. 6 Tahun 2014 tentang Desa.

Berdasarkan permasalahan makro yang diuraikan sebagai dasar pembentukan BUMDes maka dalam pengabdian yang dilakukan di Desa Napan Kecamatan Bikomi Utara juga memiliki aneka permasalahan yang dijumpai yaitu: ketersedian potensi lokal yang dimiliki belum dikelolah secara baik, adanya peluang pasar yang lebih besar dan mudah memperoleh pemasukan yang signifikan (tempat penukaran dolar dan Foto) belum dimanfaatkan secara maksimal karena secara topografi wilayah Napan merupakan pintu masuk/wilayah desa yang berbatasan langsung dengan Negara Republik Timor Leste. Dengan demikian untuk mencari alternatif menyelesaiannya maka dirumuskan permasalahan: "Bagaimanakah proses pembentukan dan pengelolaan Badan Usaha Milik Desa (BUMDes) di desa Napan Kecamatan Bikomi Utara Kabupaten Timor Tengah Utara?". Adapun tujuan dari kegiatan Pengabdian pada Masyarakat ini yaitu: a) memberikan bimbingan teknis kepada pemerintahan desa dan masyarakat mengenai proses pembentukan kepengurusan Badan Usaha Milik Desa (BUMDes) di desa Napan, Kecamatan Bikomi Utara; dan b) memberikan pemahaman kepada masyarakat dan pemerintahan desa mengenai mekanisme pengelolaan Badan Usaha Milik Desa (BUMDes) di Desa Napan Kecamatan Bikomi Utara. Manfaat kegiatan pengabdian ini antara lain a) sebagai upaya memperkuat perekonomian desa yang dibentuk berdasarkan kebutuhan dan potensi desa; b) menambah Pendapatan Asli Desa; c) terbukanya lapangan pekerjaan baru bagi warga masyarakat serta kegiatan usaha desa semakin dinamis dalam memperkuat rasa kebersamaan warga; d) memperkokoh kegotongroyongan, menumbuhkan kebanggaan dari warga terhadap desa sehingga warga menjadi kerasan tinggal di desa; dan e) mendorong tumbuhnya prakarsa dan gerakan bersama warga untuk membangun desa secara mandiri, kelestarian lingkungan hidup, dan semakin baiknya pelayanan pemerintah desa kepada warganya.

\section{METODE}

Untuk memecahkan masalah yang sudah diidentifikasi dan dirumuskan di atas, maka metode yang digunakan dalam kegiatan ini adalah metode ceramah, metode diskusi/dialog, dan metode pendampingan dan praktik. Metode ceramah digunakan untuk menyampaikan materi yang berkaitan dengan BUMDes. Metode diskusi/dialog digunakan untuk mengetahui sejauh mana pemahaman masyarakat tentang materi yang disampaikan. Sementara itu, metode pendampingan dan praktik digunakan untuk 
mengetahui potensi-potensi yang dimiliki oleh Desa Napan dan bersama masyarakat melakukan pembentukan Badan Pengurus BUMDes yang sekaligus ditetapkan dalam Surat Keputusan Kepala Desa. Selanjutnya, dilakukan pendampingan Pengurus terhadap pengelolaan BUMDes yang dilakukan Badan Pengurus di Desa Napan.

Metode-metode yang digunakan tersebut selain memberikan pemahaman tentang manajemen pengelolaan BUMDes, juga bersama pemerintahan desa dan tokoh masyarakat untuk memilih orang yang dianggap mampu dan kompeten untuk mengelolah aset desa. Sebagai dasar pembentukan badan pengurus tersebut maka dalam kegiatan ini juga melakukan pendampingan untuk perumusan PERDES tentang Badan Usaha Milik Desa (BUMDes) desa Napan Kecamatan Bikomi Utara Kabupaten TTU. Sedangkan untuk penetapan PERDES yang telah dirumuskan menjadi kewenangan pemerintahan desa Napan dan Masyarakat setempat.

\section{HASIL DAN PEMBAHASAN}

Pelaksanaan kegiatan pengabdian pada masyarakat dalam pendampingan pembentukan dan pengelolaan Bada Usaha Milik Desa di Desa Napan Kecamatan Bikomi Utara mendapat respon yang sangat baik di kalangan pemerintah desa, BPD dan masyarakat. Hal ini terlihat bahwa tingkat kehadiran dalam mengikuti kegiatan sangat baik dan antusiasme dalam merespons materi yang disampaikan sangat baik yakni a) Meningkatnya pengetahuan dan pemahaman tentang isi, maksud dan tujuan dari pada pentingnya pembentukan Badan Usaha Milik Desa (BUMDes); b) Dapat membentuk badan pengurus BUMDes; dan c) Meningkatnya pengetahuan dan pemahaman tentang kerja pengurus dalam mencegah terjadinya penyimpangan dalam pengelolaan BUMDes.

Kegiatan pengabdian kepada masyarakat yang dilakukan di Desa Napan, Kecamatan Bikomi Utara merupakan kegiatan pengabdian tentang Pendampingan Pembentukan Badan Usaha Milik Desa. Dalam kegiatan tersebut bersama Pemerintah Desa dan Badan Permusyawaratan Desa (BPD) serta Badan pengurusnya dapat merumuskan Peraturan Desa yang berhubungan dengan kepentingan pengelolaan BUMDes di desa Napan Kecamatan Bikomi Utara Kabupaten TTU. Dalam pelaksanaan kegiatan pengabdian ini menargetkan 2 (dua) dokumen penting dalam pendampingan pembentukan BUMDes yakni a) Adanya penbentukan Badan Pengurus BUMDes Desa Napan. Pendirian BUMDes Desa Napan. Dalam usaha pendirian BUMDes desa Napan Kecamatan Bikomi Utara dilakukan melalui sebuah kesepakatan bersama yaitu musyawarah Desa. Kegiatan musyawarah desa yang dilakukan di desa Napan dijalankan pada tanggal Rabu, Kegiatan ini dihadiri oleh Pemerintah Desa, Badan 
Permusyawaratan Desa (BPD) dan Masyarakat. Kegiatan ini dilakukan untuk mengidentifikasikan potensi-potensi yang dimiliki di desa dan kemudian memprioritaskan potensi yang akan dikelolah dalam Pengelolaan BUMDes Desa Napan. Adapun item kegiatan yang disepakati untuk dikelola antara lain: SP (Simpan Pinjam), Lumbung Pangan, Foto Copy

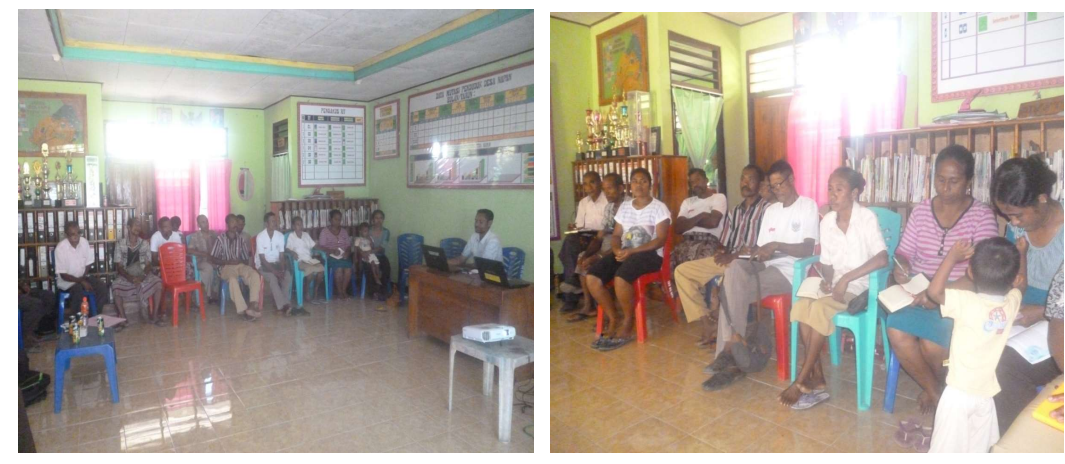

\section{Gambar 1: Pendampingan pembentukan Badan Pengurus BUMDes Desa Napan}

b) Rancangan peraturan desa/Keputusan Kepala Desa Napan tentang Pembentukan BUMDes. Rancangan Keputusan Kepala Desa Napan tentang Penetapan Badan Pengurus Badan Usaha Milik Desa Napan Kecamatan Bikomi Utara. Untuk kegiatan penyuluhan Penyusunan Rancangan Keputusan Kepala Desa Napan tentang Penetapan Badan Pengurus Badan Usaha Milik Desa (BUMDes) dilaksanakan pada Hari/Tanggal: Kamis 27 Juli 2017 dengan melibatkan Pemerintah Desa, Badan Permusyawaratan Desa (BPD), Pengelola BUMDes Napan dan Masyarakat. Dari kegiatan ini dapat melahirkan sebuah Rumusan Peraturan Desa Tentang Pembentukan BUMDes. Dalam rancangan PERDES tersebut memuat materi sebagai berikut: ketentuan Umum, Maksud dan Tujuan serta pembentukan dan Pendirian BUMDes. Rancangan Keputusan Kepala Desa tersebut akan memudahkan pemerintahan Desa (Pemerintah Desa dan BPD) untuk menetapkannya sebagai payung hukum Desa Napan yang mana dalam pembentukan BUMDes Napan sesuai kesepakatan bersama melalui musyawarah desa ditetapkan bidang usahanya bergerak dibidang Simpan Pinjam, Lumbung Pangan dan Jasa Foto Copy. Ketiga Bidang Kegiatan tersebut akan dikelola oleh Badan Pengurus BUMDes yang sudah tetapkan melalui Keputusan Kepala Desa itu. 

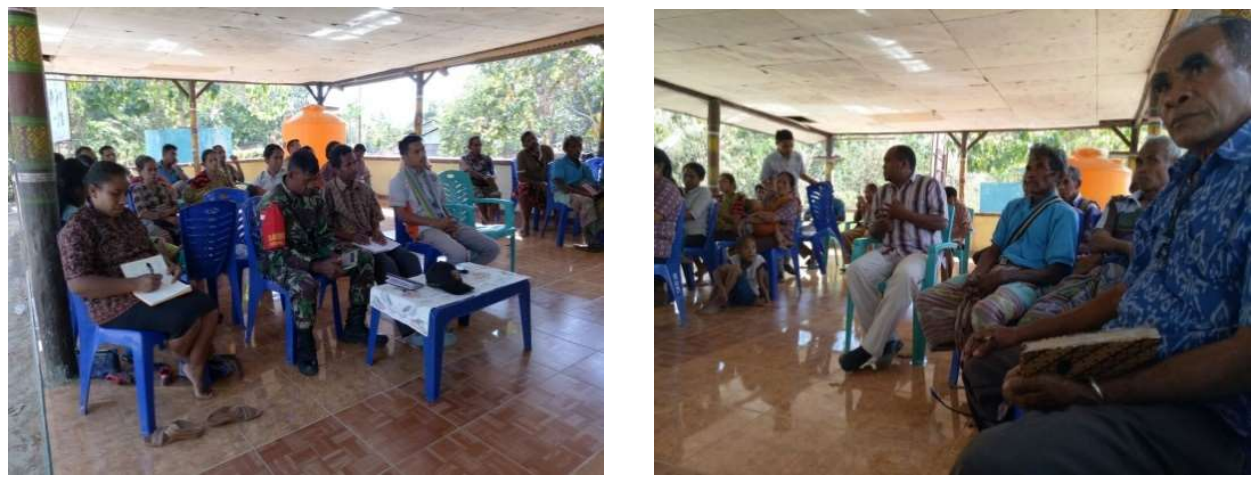

Gambar 2: Rapat Perumusan Peraturan Desa

Kedua dokumen tersebut dicapai melalui dua kegiatan yaitu penyuluhan dan pelatihan.

\section{SIMPULAN}

Dalam kegiatan pengabdian ini dihasilkan dua dokumen penting yakni dokumen pembentukan badan pengurus BUMDes Desa Napan dan dokumen peraturan Desa tentang BUMDes Desa Napan. Adapun saran-saran dalam kegiatan pengabdian ini sebagai berikut: a). Diharapkan kepada pemerintah daerah khususnya kabupaten Timor Tengah Utara untuk terus melakukan pendampingan terkait dengan pembentukan BUMDes sebagai wujud pelaksanaan UU No. 6 tahun 2014. b). Perlu dibangun kerjasama antara pemerintah daerah dan perguruan tinggi untuk tetap mendampingi dalam proses pembentukan sampai pengelolaan dan pertanggung jawaban keuangan.

\section{UCAPAN TERIMA KASIH}

Kami menyampaikan terima kasih kepada LPPM universitas Timor yang telah mendanai dan mendukung kegiatan pengabdian ini.

\section{DAFTAR PUSTAKA}

Maschab Mashuri. 2013. Politik Pemerintahan Desa di Indonesia. Yogyakarta: PolGov. Solekhan Moch. 2014, Penyelenggaraan Pemerintahan Desa Berbasis Partisipasi Masyarakat. Malang: Setara Press.

UU. Nomor 6 Tahun 2014 Tentang Desa

PP No. 43 Tahun 2014 Tentang Desa. 